\title{
Characterization of Postharvest Fungicide-Resistant Botrytis cinerea Isolates From Commercially Stored Apple Fruit
}

\author{
Wayne M. Jurick II, Otilia Macarisin, Verneta L. Gaskins, Eunhee Park, Jiujiang Yu, \\ Wojciech Janisiewicz, and Kari A. Peter
}

First, second, third, fourth, and fifth authors: United States Department of Agriculture-Agricultural Research Service (USDA-ARS), Food Quality Laboratory, Beltsville, MD; sixth author: USDA-ARS, Appalachian Fruit Research Station, Kearneysville, WV; and seventh author: Penn State University, Fruit Research and Extension Center, Biglerville, PA.

Accepted for publication 2 November 2016.

\begin{abstract}
Botrytis cinerea causes gray mold and is an economically important postharvest pathogen of fruit, vegetables, and ornamentals. Fludioxonilsensitive B. cinerea isolates were collected in 2011 and 2013 from commercial storage in Pennsylvania. Eight isolates had values for effective concentrations for inhibiting $50 \%$ of mycelial growth of 0.0004 to $0.0038 \mu \mathrm{g} / \mathrm{ml}$ for fludioxonil and were dual resistant to pyrimethanil and thiabendazole. Resistance was generated in vitro, following exposure to a sublethal dose of fludioxonil, in seven of eight dual-resistant $B$. cinerea isolates. Three vigorously growing $B$. cinerea isolates with multiresistance to postharvest fungicides were further characterized and found to be

osmosensitive and retained resistance in the absence of selection pressure. A representative multiresistant $B$. cinerea strain caused decay on apple fruit treated with postharvest fungicides, which confirmed the in vitro results. The R632I mutation in the Mrrl gene, associated with fludioxonil resistance in $B$. cinerea, was not detected in multipostharvest fungicide-resistant $B$. cinerea isolates, suggesting that the fungus may be using additional mechanisms to mediate resistance. Results from this study show for the first time that B. cinerea with dual resistance to pyrimethanil and thiabendazole can also rapidly develop resistance to fludioxonil, which may pose control challenges in the packinghouse environment and during long-term storage.
\end{abstract}

According to the U.S. Apple Association, the farm gate value of the U.S. apple crop in 2014 was valued at $\$ 2.7$ billion. Apple fruit are handpicked into bags and placed directly into wooden or plastic bins in the field for transport to the storage or packing facilities. Fruit are typically stored for up to 6 months at $1^{\circ} \mathrm{C}$ in air and can be kept for 1 year in controlled-atmosphere storage, where temperature, oxygen, and carbon dioxide are maintained at specific levels (Robinson et al. 2014). Extended storage times provide consumers with high-quality fruit year round and give the producer the opportunity to sell based on market demand. However, as fruit mature, their susceptibility to various fungal diseases increases, resulting in escalating economic losses (Xiao and Boal 2009).

Botrytis cinerea Pers. (teleomorph Botryotinia fuckeliana (de Bary) Whetzel) causes gray mold of apple fruit during storage and is a major pathogen of apple worldwide (Xiao 2014). Kim and Xiao (2008) reported that gray mold accounted for $28 \%$ of the decayed apple fruit in commercial storage in Washington State. The fungus has an extensive host range exceeding 200 plant species, including ornamentals, vegetables, and many types of fruit pre- and postharvest (Jarvis 1977). Infection primarily occurs via wounds and other surface defects that occur during and after harvest and in storage, creating infection courts that manifest in decay (Zhao et al. 2010). Control of this disease is achieved via fungicide application and cultural practices (Xiao and Boal 2009). However, the fungus remains a threat to the pome fruit industry due to its ability to reproduce rapidly and survive adverse conditions for extended periods of time, and its potential to mutate at high frequencies to overcome fungicide treatments (Fillinger et al. 2012).

Corresponding author: W. M. Jurick II;

E-mail address: Wayne.Jurick@ars.usda.gov

This article is in the public domain and not copyrightable. It may be freely reprinted with customary crediting of the source. The American Phytopathological Society, 2017.
There are four postharvest fungicides currently registered in the United States to control gray mold caused by Botrytis cinerea on apple fruit: fludioxonil (Scholar 230SC; Syngenta Crop Protection), fludioxonil + difenoconazole (Academy; Syngenta Crop Protection), pyrimethanil (Penbotec 400SC; Janssen Pharmaceutica N.V.), and thiabendazole (Mertect 340F; (Syngenta Crop Protection). Application of these products can vary according to the label but, in general, they are applied as drenches prior to storage, as dips or line sprays or in waxes during the sorting and packing process prior to storage, or thermo-fogged in storage rooms. Thiabendazole (TBZ) inhibits $\beta$-tubulin synthesis and was labeled for blue mold control in 1968 (Zhao et al. 2010). Both fludioxonil (FLU) and pyrimethanil (PYR) were registered for postharvest use on apple fruit in 2004 to control blue mold (Penicillium spp.) and gray mold (Xiao and Boal 2009). FLU inhibits the osmosensing pathway, thereby preventing conidial germination and mycelial growth (Li and Xiao 2008). PYR has preventative and curative effects and blocks spore germination, germ tube elongation, and secretion of fungal cell-wall-degradation enzymes (Kanetis et al. 2008). In 2016, a premix postharvest fungicide, Academy, was introduced to the market and contains FLU and difenoconazole (DIF), which targets the fungal osmosensing and sterol biosynthesis pathways.

The bulk of studies on resistance to FLU in $B$. cinerea have focused on naturally occurring isolates obtained from the field or packinghouse with histories of the fungicide use (Kretschmer et al. 2009; Li et al. 2014; Zhao et al. 2010). One naturally occurring $B$. cinerea isolate from apple, with reduced sensitivity to FLU, was osmosensitive, less virulent on apple fruit, and stable in the absence of fungicide selection pressure (Zhao et al. 2010). FLU-resistant $B$. cinerea isolates from blackberry were virulent on strawberry fruit, osmosensitive, and consistently associated with the arginine to isoleucine (R632I) mutation in the Mrrl gene (Li et al. 2014). Currently, there is no information concerning the potential of $B$. cinerea strains with dual resistance against two different classes of postharvest fungicides to develop resistance to FLU. This 
scenario has a strong potential to occur in the controlled environment of the packing and storage facilities following exposure to different postharvest fungicides with varying modes of action. Development of multiple postharvest fungicide-resistant strains could have a devastating effect on the pome fruit packing industry and research is needed to address fundamental questions of the fungus's ability to develop resistance, capacity to retain acquired resistance, and decaycausing potential on postharvest fungicide-treated fruit. Therefore, the objectives of this investigation were to (i) determine the potential of dual-postharvest fungicide (PYR/TBZ)-resistant $B$. cinerea isolates to develop resistance to FLU in vitro; (ii) characterize in vitro growth, osmotic sensitivity, and retention of a multipostharvest fungicide resistance phenotype of $B$. cinerea isolates; (iii) determine the efficacy of three postharvest fungicides registered for pome fruit to control gray mold caused by a multifungicide-resistant $B$. cinere $a$ strain; and (iv) examine the C-terminal portion of the $M r r l$ transcription factor in $B$. cinerea isolates to investigate the potential mechanisms of resistance.

\section{MATERIALS AND METHODS}

Fungal isolates, fungicides, and fruit. In total, $110 \mathrm{~B}$. cinerea isolates were obtained from decayed apple fruit with gray mold symptoms from a commercial storage facility with a history of postharvest fungicide use located in Pennsylvania in 2011 and 2013. These isolates were obtained from decayed 'Fuji' and 'Gala' apple fruit with gray mold symptoms. Eight of these isolates were selected based on their sensitivity to FLU and resistance to TBZ and PYR, high rate of sporulation, and vigorous growth in culture. These eight isolates were started from single-spore cultures and maintained on potato dextrose agar (PDA) agar at $4^{\circ} \mathrm{C}$. Technical-grade stocks of FLU, TBZ, and PYR were obtained from Sigma-Aldrich and used for all in vitro tests. Concentrated stock solutions of 10,000 $\mu \mathrm{g} / \mathrm{ml}$ were prepared by dissolving them in appropriate solvents for FLU (acetone), PYR (acetone), and TBZ (dimethyl sulfoxide) and kept in the dark at $4^{\circ} \mathrm{C}$. Commercial formulations of these postharvest fungicides-Scholar 230SC (Syngenta Crop Protection), Penbotec 400SC (Janssen Pharmaceutica N.V.), and Mertect 340F (Syngenta Crop Protection) - were used in the apple decay tests. 'Golden Delicious' apple fruit were harvested at the Penn State Fruit Research and Extension Center in Biglerville, PA at commercial maturity, with average starch scores of 5 on an 8-point scale. No preharvest fungicides with postharvest efficacy or postharvest fungicides were applied to these apple fruit and they were stored on commercial tray packs in cardboard apple boxes at $1^{\circ} \mathrm{C}$ in air.

Fungicide phenotyping and determination of effective concentrations for inhibiting $\mathbf{5 0 \%}$ of mycelial growth. The fungicide phenotype for eight $B$. cinerea isolates was determined using discriminatory doses previously determined by Zhao et al. (2010). Briefly, 4.5-cm petri dishes containing PDA amended with FLU $(0.5 \mu \mathrm{g} / \mathrm{ml})$ or TBZ $(10 \mu \mathrm{g} / \mathrm{ml})$ and Richard's defined medium amended with PYR $(1.0 \mu \mathrm{g} / \mathrm{ml})$ were inoculated with $4-\mathrm{mm}$ mycelial plugs taken from the margin of a 7-day-old $B$. cinerea colony actively growing on PDA. There were three replicates per treatment. An isolate was considered resistant if new mycelial growth was observed 3 days postinoculation onto the amended medium. Effective concentrations for inhibiting $50 \%$ of mycelial growth $\left(\mathrm{EC}_{50}\right)$ were determined for FLU using 0, 0 + carrier, 0.0001, 0.001, 0.01, 0.1 , and $1.0 \mu \mathrm{g} / \mathrm{ml}$ for FLU-sensitive dual-resistant isolates and 0 , $0+$ carrier, $0.01,0.1,1.0,10$, and $50 \mu \mathrm{g} / \mathrm{ml}$ for multiple-resistant $B$. cinerea strains with conditioned resistance to FLU. Mycelial plugs (6.25 $\mathrm{mm}$ in diameter) of $B$. cinerea, were transferred onto the PDA with FLU, and incubated for 3 days at $20^{\circ} \mathrm{C}$ with 12 -h cycles of light and darkness. Colony diameter was recorded for each concentration using a digital micrometer.

Generating FLU resistance in vitro. Eight dual-resistant $B$. cinerea isolates were grown on PDA with the lowest dose of FLU $(0.065 \mu \mathrm{g} / \mathrm{ml})$ that would support mycelial growth in culture. After growth on the sublethal dose, three hyphal plugs from the margin of actively growing colonies were transferred to PDA plates with different concentrations of FLU $(0.1,0.25$, and $0.5 \mu \mathrm{g} / \mathrm{ml})$ in triplicate. The number of plates on which the fungus grew containing fungicide-amended medium was recorded and expressed as the percentage of the total number of plates inoculated for a given concentration (percent growth). Five days postinoculation, isolates that grew on FLU-PDA at $0.5 \mu \mathrm{g} / \mathrm{ml}$ were transferred to $0.5-\mu \mathrm{g} / \mathrm{ml}$ FLU-PDA plates, and this was repeated. Three vigorously growing isolates on the discriminatory dose of FLU at $0.5 \mu \mathrm{g} / \mathrm{ml}$ were designated $-\mathrm{C}$ (for conditioned) and selected for further characterization. One isolate, 3RGA27, did not grow directly on FLU-PDA at $0.5 \mu \mathrm{g} / \mathrm{ml}$ postconditioning. Therefore, it was propagated in stepwise fashion on FLU-PDA at $0.1,0.25$, and $0.5 \mu \mathrm{g} / \mathrm{ml}$. The isolate was capable of growing on FLU-PDA at $0.5 \mu \mathrm{g} / \mathrm{ml}$ after a stepwise process but died upon subsequent transfer to FLU-PDA at $0.5 \mu \mathrm{g} / \mathrm{ml}$. All treatments contained three replicates.

Polymerase chain reaction and phylogenetic analysis. Genomic DNA was extracted from fungal cultures grown on PDA colonized plates. Fungal mycelium, with the agar removed, was extracted with the Sigma Extract-N-Amp kit to obtain genomic DNA. Glyceraldehyde-3-phosphate dehydrogenase (G3PDH) and Mrrl transcription factor genes were amplified using conventional polymerase chain reaction (PCR) and primers designed according to Li et al. (2014) and Grant-Downton et al. (2014) (Table 1). Each amplicon was sequenced using the Sanger method at the University of Florida Interdisciplinary Center for Biotechnology Research sequencing lab and a $2 \times$ consensus was subjected to a MegaBLAST analysis for species-level identification. The partial Mrrl gene was translated using in silico tools and compared with other Mrrl peptide sequences obtained from GenBank. Multiple sequence alignment was achieved using ClustalW and residue 632 was examined for the nonsynonymous mutation ( $\mathrm{R}$ to $\mathrm{I}$ ) that has been reported to coincide with resistance to FLU. B. cinerea nucleotide sequences were obtained from GenBank associated with published sources and aligned using MUSCLE. A phylogenetic tree was constructed using maximum-likelihood parsimony (unweighted pair-group method with arithmetic means, Jukes-Cantor model) in the CLC Genomics Workbench, version 7.5.1. Bootstrap analysis was performed with a $70 \%$ threshold. Both Sclerotinia sclerotiorum and $B$. allii were included in the analysis as outgroups.

In vitro growth rate and stability of fungicide resistance. $B$. cinerea isolates were grown on five types of media: tryptic soy agar (TSA), malt extract agar (MEA), V8 agar (V8), PDA, and PDA with $4 \% \mathrm{NaCl}$. Conditioned isolates were grown on PDA and PDA containing $4 \% \mathrm{NaCl}$. Plates were incubated at $20^{\circ} \mathrm{C}$ with 12 -h cycles of light and darkness, and colony diameters were measured using a digital micrometer. To evaluate the stability of FLU, PYR, and TBZ resistance, three conditioned isolates were cultured for 10 generations on PDA without selection in triplicate. Following the 10th generation, each isolate was transferred to either PDA containing FLU at $0.5 \mu \mathrm{g} / \mathrm{ml}$ or TBZ at $10 \mu \mathrm{g} / \mathrm{ml}$ and Richard's defined medium containing PYR at $1.0 \mu \mathrm{g} / \mathrm{ml}$ and assessed for growth. Each isolate was tested in triplicate and the experiments were repeated.

Efficacy of postharvest fungicides to control gray mold on apple fruit. Conditioned multiresistant isolate B9F-C (resistant to FLU, PYR, and TBZ) and parental dual-resistant isolate B9F-P (sensitive to FLU, resistant to PYR and TBZ) were selected

TABLE 1. Primer names, sequences, and resulting amplicon sizes used for characterization of Botrytis cinerea isolates

\begin{tabular}{llc}
\hline Primer name & \multicolumn{1}{c}{ Sequence 5'-3' } & Amplicon size (bp) \\
\hline BcMrr1-F & tgcgtacagctatggcattc & 631 \\
BcMrr1-R & $\begin{array}{l}\text { ccccacatctctggattttg } \\
\text { gatggattggaggtcaatgg }\end{array}$ & $\ldots$ \\
Bc-G3PDH-F & gtcaccgttcatgtcagtgg & $\ldots$ \\
Bc-G3PDH-R & $\ldots$ \\
\hline
\end{tabular}


for further evaluation based on their ability to grow vigorously and sporulate well in culture. Apple fruit were washed with soap and water and dried with sterile paper towels, then sanitized by spraying with $70 \%$ ethanol to runoff. The fruit were dried once more with paper towels and placed on 20-count cardboard trays. Apple fruit were wounded once at the equator with the point of a finishing nail to a depth of $3 \mathrm{~mm}$ and wound inoculated with $20 \mu \mathrm{l}$ of a $B$. cinerea conidial suspension adjusted to $1 \times 10^{4} \mathrm{conidia} / \mathrm{ml}$. One hour after inoculation, fruit were dipped for $30 \mathrm{~s}$ with constant agitation in either deionized water or one of the three fungicide solutions of Scholar 230SC (0.94 ml/liter), Mertect 340F (1.25 ml/liter), or Penbotec 400SC (1.25 ml/liter) at rates indicated on the fungicide labels (Zhao et al. 2010). After dip treatment, the fruit were air dried for $30 \mathrm{~min}$, placed on trays, and stored in cardboard apple boxes for 7 days at $22^{\circ} \mathrm{C}$ in the dark. Lesion diameters originating from each wound were measured. The incidence of decay and disease severity were calculated. Twenty fruit were used for each treatment and the experiment was repeated.

Statistical analysis. All experiments were performed at least twice unless indicated otherwise. Data from independent experiments were pooled for analysis only if they were not deemed statistically different $(P>0.05)$ via an $F$ test for equality of variances. Linear regression of percent inhibition of mycelial growth relative to the control versus logarithmic transformation for each concentration of FLU was carried out using SAS PROC REG (version 9.1; SAS Institute) and the $\mathrm{EC}_{50}$ values were calculated. All percentage data were arcsine-square-root transformed prior to analysis so to not violate analysis of variance assumptions. Mycelial growth rate, percent survival, and decay analysis of apple fruit were analyzed using analysis of variance (PROC GLM) in SAS, and means were separated by the Waller-Duncan K-ratio $t$ test, where $K=100$.

\section{RESULTS}

Characterization of $\boldsymbol{B}$. cinerea isolates. Growth on different media and $\mathrm{EC}_{50}$ of eight $B$. cinerea isolates are shown in Table 2. All isolates were determined to be sensitive to FLU but were dual resistant to PYR and TBZ using discriminatory doses of $0.5,1.0$, and $10 \mu \mathrm{g} / \mathrm{ml}$, similarly to those previously reported by Zhao et al. (2010). For FLU, the $\mathrm{EC}_{50}$ was 0.0004 to $0.0038 \mu \mathrm{g} / \mathrm{ml}$. Mycelial growth was determined on three separate types of media and the isolates grew best on MEA, with growth of 4.89 to $7.15 \mathrm{~mm} /$ day, and on V8, with 4.44 to $7.18 \mathrm{~mm} /$ day, and significantly less on TSA, with growth of 1.66 to $4.08 \mathrm{~mm} /$ day (Table 2).

Multiple sequence alignment of the C-terminal region of the Mrrl locus revealed the presence of an arginine residue at position 632 in all parental isolates, including those obtained from GenBank for comparison that were FLU sensitive (MC14) and a B. cinerea
(CB82a) strain from blackberry with low resistance to FLU (Fig. 1A). Isolate KC33 was moderately resistant to FLU (capable of growth on FLU at $10 \mu \mathrm{g} / \mathrm{ml}$ ) and was included to show the isoleucine residue at position 632 that coincides with FLU resistance. Three representative $B$. cinerea isolates with conditioned resistance to FLU (B9F, 3RGA36, and 3RGA39) growing with FLU at 0.5, 1.0 and $10 \mu \mathrm{g} / \mathrm{ml}$ were analyzed for the R631I mutation alongside three isolates from blackberry (sequences obtained from GenBank) that were sensitive, low resistant, and moderately resistant to FLU. Unexpectedly, arginine was found at position 632 in all isolates capable of growing on three different concentrations of FLU (Fig. 1B).

BLAST analysis of $2 \times$ consensus for the G3PDH gene matched $100 \%$ with other $B$. cinerea isolates in the GenBank and confirmed the species-level identification. These sequences were also used to assess phylogenetic relationships of the $B$. cinerea isolates from Pennsylvania and other geographic locations (Fig. 2). Phylogenetic analysis using the G3PDH locus showed that the isolates from Pennsylvania composed a distinct clade, with $100 \%$ bootstrap support, differing from isolates from South Carolina, China, and The Netherlands. Sequence data from S. sclerotiorum 1980 and B. allii MUCL43 were included as outgroups.

Generating conditioned resistance to FLU. Growth on a sublethal dose of FLU $(0.065 \mu \mathrm{g} / \mathrm{ml})$ followed by transfer to either $0.1,0.25$ or $0.5 \mu \mathrm{g} / \mathrm{ml}$ resulted in all isolates growing at the lowest concentration of FLU; however, apparent variation in growth was observed among the isolates challenged at the higher concentrations (Table 2). Interestingly, one isolate (3RGA27) did not grow with FLU at 0.25 or $0.5 \mu \mathrm{g} / \mathrm{ml}$ postconditioning (Table 2). Therefore, to determine whether this isolate could reach the discriminatory dose of FLU at $0.5 \mu \mathrm{g} / \mathrm{ml}$, it was transferred in a stepwise fashion from 0.1 to 0.25 and then $0.5 \mu \mathrm{g} / \mathrm{ml}$ (data not shown). This isolate did not grow upon subsequent transfer on PDA amended with a discriminatory dose of FLU (Table 3). Isolates B9F, 3RGA36, and 3RGA39 grew vigorously on PDA amended with FLU at $0.5 \mu \mathrm{g} / \mathrm{ml}$; they were designated $-\mathrm{C}$ and selected for further characterization.

Three multiple-resistant $B$. cinerea isolates (B9F-C, 3RGA36-C, and 3RGA39-C) with conditioned resistance to FLU were analyzed for $\mathrm{EC}_{50}$, resistance to PYR and TBZ, growth rate on PDA and PDA amended with $4 \% \mathrm{NaCl}$, and stability of resistance and compared with their parental FLU-sensitive strains (Table 4). $\mathrm{EC}_{50}$ for FLU in conditioned isolates was $>50 \mu \mathrm{g} / \mathrm{ml}$ for all three strains, which is several orders of magnitude higher than their respective parental isolates, which ranged from 0.0021 to $0.0023 \mu \mathrm{g} / \mathrm{ml}$. Development of FLU resistance did not affect dual resistance to PYR and TBZ and was determined to be stable after 10 successive generations in the absence of selection pressure (Table 4). The growth rate of conditioned isolates was approximately half that of the parental

TABLE 2. Characterization of Botrytis cinerea isolates from Pennsylvania for fungicide resistance and growth rates on different media

\begin{tabular}{|c|c|c|c|c|c|c|}
\hline \multirow[b]{2}{*}{ Isolate $^{w}$} & \multirow[b]{2}{*}{ Cultivar $^{\mathrm{x}}$} & \multirow[b]{2}{*}{$\mathrm{EC}_{50}(\mu \mathrm{g} / \mathrm{ml})^{\mathrm{y}}$} & \multirow[b]{2}{*}{ Fungicide phenotype ${ }^{\mathrm{z}}$} & \multicolumn{3}{|c|}{ Mycelial growth $(\mathrm{mm} / \text { day })^{\mathrm{v}}$} \\
\hline & & & & TSA & MEA & V8 \\
\hline B9F & Fuji & 0.0021 & $\mathrm{FLU}_{\mathrm{S}} \mathrm{PYR}_{\mathrm{R}} \mathrm{TBZ}_{\mathrm{R}}$ & $2.54 \mathrm{~b}$ & $6.35 \mathrm{a}$ & $5.67 \mathrm{a}$ \\
\hline 3RGA9 & Gala & 0.0024 & $\mathrm{FLU}_{\mathrm{S}} \mathrm{PYR}_{\mathrm{R}} \mathrm{TBZ}_{\mathrm{R}}$ & $3.00 \mathrm{~b}$ & $4.89 \mathrm{a}$ & $4.97 \mathrm{a}$ \\
\hline 3RGA22 & Gala & 0.0038 & $\mathrm{FLU}_{\mathrm{S}} \mathrm{PYR}_{\mathrm{R}} \mathrm{TBZ}_{\mathrm{R}}$ & $2.76 \mathrm{~b}$ & $6.52 \mathrm{a}$ & $7.18 \mathrm{a}$ \\
\hline 3RGA27 & Gala & 0.0004 & $\mathrm{FLU}_{\mathrm{S}} \mathrm{PYR}_{\mathrm{R}} \mathrm{TBZ}_{\mathrm{R}}$ & $1.70 \mathrm{~b}$ & $6.00 \mathrm{a}$ & $4.55 \mathrm{a}$ \\
\hline 3RGA33 & Gala & 0.0033 & $\mathrm{FLU}_{\mathrm{S}} \mathrm{PYR}_{\mathrm{R}} \mathrm{TBZ}_{\mathrm{R}}$ & $2.81 \mathrm{~b}$ & $6.39 \mathrm{a}$ & $5.75 \mathrm{a}$ \\
\hline 3RGA36 & Gala & 0.0023 & $\mathrm{FLU}_{\mathrm{S}} \mathrm{PYR}_{\mathrm{R}} \mathrm{TBZ}_{\mathrm{R}}$ & $1.66 \mathrm{~b}$ & $7.15 \mathrm{a}$ & $5.95 \mathrm{a}$ \\
\hline 3RGA37 & Gala & 0.0024 & $\mathrm{FLU}_{\mathrm{S}} \mathrm{PYR}_{\mathrm{R}} \mathrm{TBZ}_{\mathrm{R}}$ & $4.08 \mathrm{~b}$ & $6.39 \mathrm{a}$ & $6.65 \mathrm{a}$ \\
\hline 3RGA39 & Gala & 0.0021 & $\mathrm{FLU}_{\mathrm{S}} \mathrm{PYR}_{\mathrm{R}} \mathrm{TBZ}_{\mathrm{R}}$ & $3.50 \mathrm{~b}$ & $6.02 \mathrm{a}$ & $5.95 \mathrm{a}$ \\
\hline
\end{tabular}

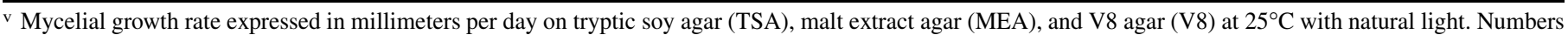
within the same row for a given medium followed by different letters are statistically significant according to the Waller-Duncan $K$-ratio $t$ test, where $K=100$.

w All cultures are maintained at United States Department of Agriculture-Agricultural Research Service Food Quality Laboratory in Beltsville, MD.

x B. cinerea was isolated from decayed apple fruit from a commercial storage facility in Pennsylvania and propagated as monoconidial cultures.

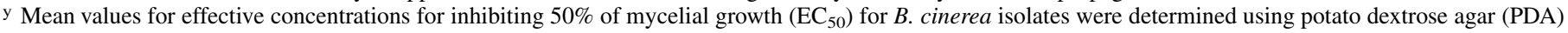
amended with technical-grade fludioxonil and calculated using linear regression models in SAS.

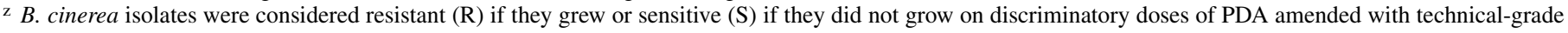
fludioxonil (FLU) at $0.5 \mu \mathrm{g} / \mathrm{ml}$, Richard's defined medium amended with pyrimethanil (PYR) at $1 \mu \mathrm{g} / \mathrm{ml}$, or PDA with thiabendazole (TBZ) at $10 \mu \mathrm{g} / \mathrm{ml}$. 
A

$\mathrm{B} 9 \mathrm{~F}-\mathrm{P}$

3RGA9B-P

3RGA2 2B-P

3RGA2 7B-P

3RGA33B-P

3RGA36B-P

$3 R G A 37 B-P$

3RGA39B-P

$\mathrm{MC} 14-\mathrm{S}(0)$

$\mathrm{CB} 82 \mathrm{a}-\mathrm{LR}(1.0)$

KC33-MR (10.0)
ELCAEPTGPLADQAWEGIEFHYNKWSEFVADTKDGMIWRPVRNLMKRARAARRRERGLSE ELCAEPTGPLADQAWEGIEFHYNKWSEFVADTKDGMIWRPVRNLMKRARAARRRERGLSE ELCAEPTGPLADQAWEGIEFHYNKWSEFVADTKDGMIWRPVRNLMKRARAARRRERGLSE ELCAEPTGPLADQAWEGIEFHYNKWSEFVADTKDGMIWRPVRNLMKRARAARRRERGLSE ELCAEPTGPLADQAWEGIEFHYNKWSEFVADTKDGMIWRPVRNLMKRARAARRRERGLSE ELCAEPTGPLADQAWEGIEFHYNKWSEFVADTKDGMIWRPVRNLMKRARAARRRERGLSE ELCAEPTGPLADQAWEGIEFHYNKWSEFVADTKDGMIWRPVRNLMKRARAARRRERGLSE ELCAEPTGPLADQAWEGIEFHYNKWSEFVADTKDGMIWRPVRNLMKRARAARRRERGLSE ELCAEPTGPLADQAWEGIEFHYNKWSEFVADTKDGMIWRPVRNLMKRARAARRRERGLSE ELCAEPTGPLADQAWGS IEFHYNKWSEFVADTKDGMIWRPVKNLMKRARAARRRERGLSE ELCAEPTGPLADQAWGS IEFHYNKWSEFVADTKDGMIWRPVKNLMKIARAARRRERGLSE

B

$\mathrm{B} 9 \mathrm{~F}-\mathrm{C}(0.5)$

$\mathrm{B} 9 \mathrm{~F}-\mathrm{C}(1.0)$

B9F-C (10.0)

$3 R G A 36 B-C(0.5)$

ELCAEPTGPLADQAWEGIEFHYNKWSEFVADTKDGMIWRPVRNLMKRARAARRRERGLSE ELCAEPTGPLADQAWEGIEFHYNKWSEFVADTKDGMIWRPVRNLMKRARAARRRERGLSE ELCAEPTGPLADQAWEGIEFHYNKWSEFVADTKDGMIWRPVRNLMKRARAARRRERGLSE

$3 R G A 36 B-C(1.0)$ ELCAEPTGPLADQAWEGIEFHYNKWSEFVADTKDGMIWRPVRNLMKRARAARRRERGLSE

3RGA36B-C $(10.0)$ ELCAEPTGPLADQAWEGIEFHYNKWSEFVADTKDGMIWRPVRNLMKRARAARRRERGLSE 3RGA39B-C (0.5) ELCAEPTGPLADQAWEGIEFHYNKWSEFVADTKDGMIWRPVRNLMKRARAARRRERGLSE 3RGA39B-C (1.0) ELCAEPTGPLADQAWEGIEFHYNKWSEFVADTKDGMIWRPVRNLMKRARAARRRERGLSE 3RGA39B-C (10.0) ELCAEPTGPLADQAWEGIEFHYNKWSEFVADTKDGMIWRPVRNLMKRARAARRRERGLSE $\mathrm{MC} 14-\mathrm{S}(0)$ CB82a-LR (1.0) KC33-MR (10.0) ELCAEPTGPLADQAWEGIEFHYNKWSEFVADTKDGMIWRPVRNLMKRARAARRRERGLSE ELCAEPTGPLADQAWGS IEFHYNKWSEFVADTKDGMIWRPVKNLMKRARAARRRERGLSE ELCAEPTGPLADOAWGS IEFHYNKWSEFVADTKDGMIWRPVKNLMKIARAARRRERGLSE

Fig. 1. Multiple amino acid sequence alignment of the Mrrl C-terminus using MUSCLE highlighting (shaded) the amino acid residue (R632I) associated with resistance to fludioxonil for $\mathbf{A}$, parental (-P; dual-resistant and fludioxonil-sensitive) and $\mathbf{B}$, conditioned (-C; multiresistant and fludioxonil-resistant) Botrytis cinerea isolates capable of growing on potato dextrose agar amended with fludioxonil at $0.5,1.0$, and $10 \mu \mathrm{g} / \mathrm{ml}$. Additional isolates for comparison were obtained from GenBank. $\mathrm{S}=$ sensitive, $\mathrm{LR}=$ low resistant, and $\mathrm{MR}=$ moderately resistant to fludioxonil.

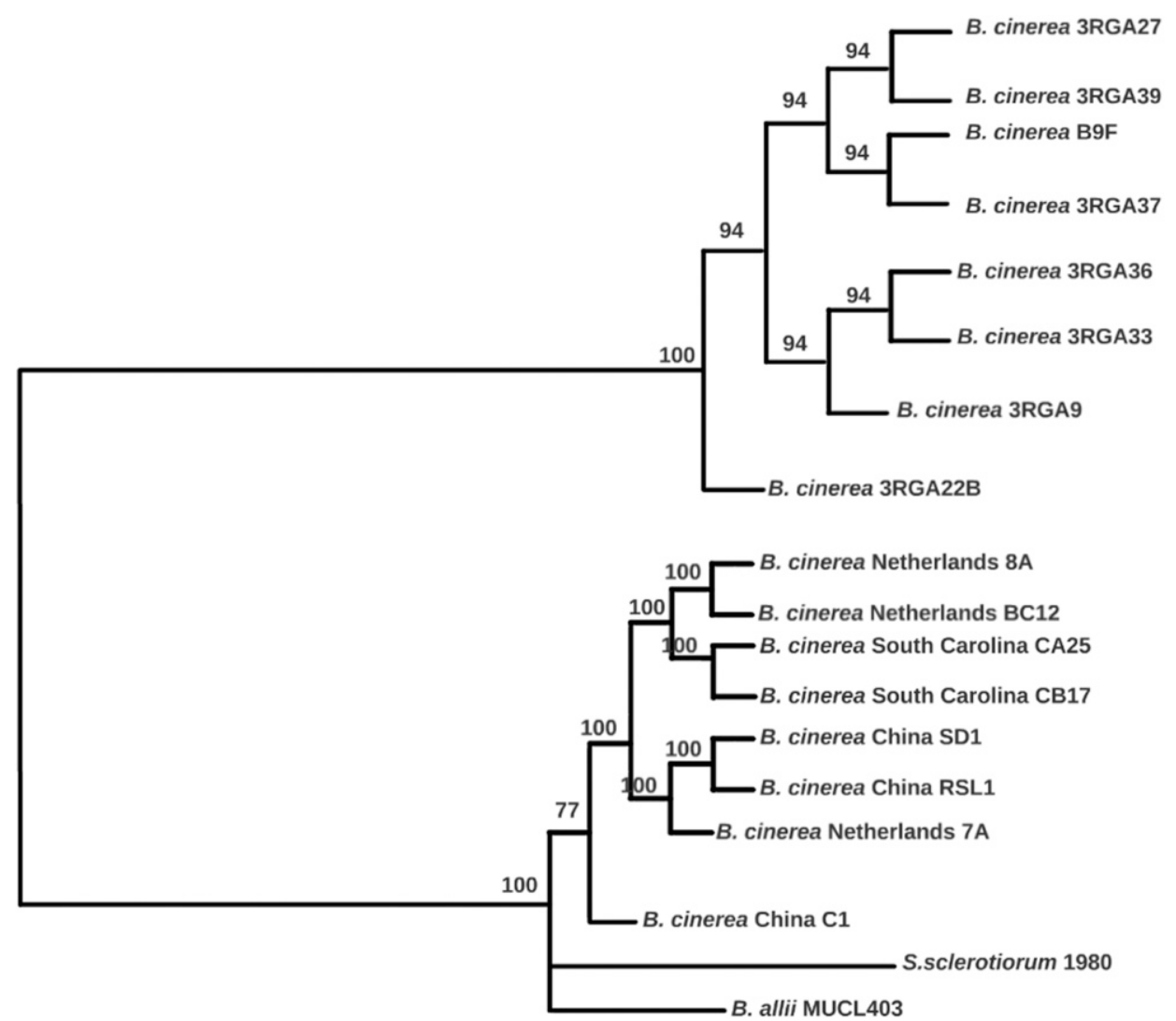

Fig. 2. Phylogenetic tree of Botrytis cinerea isolates using highly conserved locus glyceraldehyde-3-phosphate dehydrogenase. In addition to nucleotide sequences for Pennsylvania isolates, sequences were also obtained for $B$. cinerea from The Netherlands, China, and South Carolina and for designated outgroups $B$. allii and Sclerotinia sclerotiorum from GenBank. Sequences were aligned using MUSCLE, trimmed, and analyzed using maximum-likelihood phylogeny. Statistical support for each branch is indicated by bootstrap values (1,000 replicates). 
strains on PDA and they were osmosensitive, with growth significantly reduced on PDA amended with $4 \% \mathrm{NaCl}$.

Efficacy of postharvest fungicides to control gray mold on apple. Golden Delicious apple fruit inoculated with either dual-resistant (FLU-sensitive) or multiple-resistant (FLU-resistant) $B$. cinerea isolates and treated with three different postharvest fungicides to determine their effectiveness in controlling gray mold (Table 5). Decay was observed on apple fruit inoculated with a B9F dual-resistant parental isolate treated with Mertect (TBZ) and Penbotec (PYR) but not with Scholar (FLU). Decay incidence and severity were not significantly different between untreated and Mertect-treated apple fruit but were significantly lower in Penbotec and Scholar treatments (Table 5). Decay was observed on Mertect-, Penbotec-, and Scholar-treated apple fruit when inoculated with the multiresistant B9F-C isolate that was resistant to Mertect, Penbotec, and Scholar. Decay incidence was significantly higher on Scholar and was lowest on Penbotec-treated fruit. However, mean lesion sizes of infected apple fruit were not statistically different for untreated or Mertect- and Penbotec-treated apple fruit but were significantly smaller in Scholar-treated fruit.

\section{DISCUSSION}

B. cinerea isolates from Pennsylvania had $\mathrm{EC}_{50}$ values that were similar to FLU-sensitive baseline isolates from apple in the United States and comparable with those from strawberry in northeastern Switzerland (Hilber et al. 1995; Zhao et al. 2010). This indicates that the $B$. cinerea isolates investigated in the

TABLE 3. Growth of dual-resistant Botrytis cinerea isolates on potato dextrose agar amended with various concentrations of technical-grade fludioxonil

\begin{tabular}{lcccc}
\hline & \multicolumn{4}{c}{ Growth $(\%)$ with fludioxonil $(\mu \mathrm{g} / \mathrm{ml})^{\mathrm{z}}$} \\
\cline { 2 - 5 } Isolate name & 0.065 & 0.1 & 0.25 & 0.5 \\
\hline B9F & 100 & 100 & 83 & $100^{*}$ \\
3RGA9 & 100 & 100 & 50 & 33 \\
3RGA22 & 100 & 100 & 67 & 67 \\
3RGA27 & 100 & 100 & 0 & 0 \\
3RGA33 & 100 & 100 & 33 & 50 \\
3RGA36 & 100 & 100 & 67 & $33^{*}$ \\
3RGA37 & 100 & 100 & 83 & 67 \\
3RGA39 & 100 & 100 & 50 & $67^{*}$ \\
\hline
\end{tabular}

${ }^{\mathrm{z}}$ Percent growth was calculated by dividing the number of plates with growth by the total number of mycelial plugs inoculated onto a given dose of fludioxonil-amended potato dextrose agar (PDA). A sublethal dose of fludioxonil $(0.065 \mu \mathrm{g} / \mathrm{ml})$ was used to condition isolates prior to subsequent transfer to higher doses of fludioxonil from 0.1 to $0.5 \mu \mathrm{g} / \mathrm{ml}$. An asterisk (*) indicates vigorous mycelial growth after two transfers to PDA containing fludioxonil at $0.5 \mu \mathrm{g} / \mathrm{ml}$. current study have similar levels of sensitivity to FLU compared with isolates from other geographically distinct areas. The isolates were also found to have dual resistance to TBZ and PYR, which has not been demonstrated to date for $B$. cinerea from pome fruit but has been shown for laboratory-generated mutants of Penicillium expansum (Li and Xiao 2008). The parental isolates were obtained from a major commercial packing and storage facility in Pennsylvania with a history of postharvest fungicide use, which may explain their dual fungicide resistance phenotypes. The concept of fungicidedriven evolution to multiple fungicide classes has been shown for field populations of $B$. cinerea from small fruit in the United States and on wine grapes in Europe, which supports our findings (Fernández-Ortuño et al. 2015; Kretschmer et al. 2009). Although scientifically interesting, these results are troubling from a practical standpoint because dual- or multiple-fungicideresistant isolates would be difficult to control in the packinghouse environment, considering that there are only four currently labeled fungicides for control of postharvest gray mold on apple. These results also reinforce the need for additional research to develop new strategies for gray mold control to maintain apple fruit quality during long-term storage.

Genetic characterization of the parental isolates was conducted using a highly conserved locus that has been implemented in Botrytis speciation and phylogeny studies (Grant-Downton et al.

TABLE 5. Control of Botrytis cinerea dual-resistant parental (P) or multiresistant conditioned $(\mathrm{C})$ isolates on wound-inoculated apple fruit treated with labeled rates of commercial postharvest fungicides (Scholar, Penbotec, and Mertect) stored at $20^{\circ} \mathrm{C}$ for 7 days

\begin{tabular}{lcc}
\hline Isolate, phenotype, treatment & Incidence $(\%)$ & Lesion size $(\mathrm{mm})^{\mathrm{z}}$ \\
\hline B9F-P, FLU ${ }_{\mathrm{S}} \mathrm{PYR}_{\mathrm{R}} \mathrm{TBZ}_{\mathrm{R}}$ & & \\
Untreated & $100 \mathrm{a}$ & $59.5 \mathrm{a}$ \\
Mertect & $100 \mathrm{a}$ & $60.3 \mathrm{a}$ \\
Penbotec & $92.5 \mathrm{~b}$ & $45.6 \mathrm{~b}$ \\
Scholar & $0 \mathrm{c}$ & $0 \mathrm{c}$ \\
B9F-C, FLU $\mathrm{R}_{\mathrm{R}} \mathrm{PR}_{\mathrm{R}} \mathrm{TBZ}_{\mathrm{R}}$ & & \\
Untreated & $37.5 \mathrm{ab}$ & $24.2 \mathrm{a}$ \\
Mertect & $22.5 \mathrm{~b}$ & $25.3 \mathrm{a}$ \\
Penbotec & $2.50 \mathrm{c}$ & $33.8 \mathrm{a}$ \\
Scholar & $45.0 \mathrm{a}$ & $7.93 \mathrm{~b}$ \\
\hline
\end{tabular}

${ }^{y} \mathrm{FLU}=$ fludioxonil, $\mathrm{PYR}=$ pyrimethanil, $\mathrm{TBZ}=$ thiabendazole, $\mathrm{S}=$ sensitive, and $\mathrm{R}=$ resistant. Untreated, Mertect, Penbotec, and Scholar were applied as sterile deionized water, Mertect $340 \mathrm{~F}$ at $1.25 \mathrm{ml} / \mathrm{liter}$, Penbotec $400 \mathrm{SC}$ at $1.25 \mathrm{ml} /$ liter, and Scholar 230SC at $0.94 \mathrm{ml} /$ liter, respectively.

${ }^{\mathrm{z}}$ Lesion size in millimeters represents the lesion diameter, including the wound of approximately $3 \mathrm{~mm}$. Values within a column for each isolate followed by a different letter are significantly different according to the Waller-Duncan $K$-ratio $t$ test, where $K=100(P=0.05)$.

TABLE 4. Fungicide sensitivity and phenotypic characteristics of dual-resistant parental and multiresistant conditioned isolates from Pennsylvania

\begin{tabular}{|c|c|c|c|c|c|}
\hline \multirow[b]{2}{*}{ Isolate name ${ }^{\mathrm{w}}$} & \multirow[b]{2}{*}{$\mathrm{EC}_{50}(\mu \mathrm{g} / \mathrm{ml})^{\mathrm{x}}$} & \multirow[b]{2}{*}{ Fungicide phenotype $^{y}$} & \multicolumn{2}{|c|}{ Growth rate $(\mathrm{mm} /$ day $)$ on $^{v}$} & \multirow[b]{2}{*}{ Phenotype $^{z}$} \\
\hline & & & PDA & $\mathrm{PDA}+4 \% \mathrm{NaCl}$ & \\
\hline B9F-P & 0.0021 & $\mathrm{FLU}_{\mathrm{S}} \mathrm{PYR}_{\mathrm{R}} \mathrm{TBZ}_{\mathrm{R}}$ & $10.4 \mathrm{a}$ & $9.8 \mathrm{~b}$ & nd \\
\hline 3RGA36-P & 0.0023 & FLU $_{S} P Y R_{R} T B Z_{R}$ & $7.0 \mathrm{~b}$ & $7.3 \mathrm{c}$ & nd \\
\hline B9F-C & $>50$ & $\mathrm{FLU}_{\mathrm{R}} \mathrm{PYR}_{\mathrm{R}} T B Z_{\mathrm{R}}$ & $5.9 \mathrm{c}$ & $3.1 \mathrm{~d}$ & $\mathrm{FLU}_{\mathrm{R}} \mathrm{PYR}_{\mathrm{R}} \mathrm{TBZ}_{\mathrm{R}}$ \\
\hline 3RGA36-C & $>50$ & $\mathrm{FLU}_{\mathrm{R}} \mathrm{PYR}_{\mathrm{R}} \mathrm{TBZ}_{\mathrm{R}}$ & $4.4 \mathrm{~d}$ & $3.2 \mathrm{e}$ & $\mathrm{FLU}_{\mathrm{R}} \mathrm{PYR}_{\mathrm{R}} \mathrm{TBZ}$ \\
\hline 3RGA39-C & $>50$ & $\mathrm{FLU}_{\mathrm{R}} \mathrm{PYR}_{\mathrm{R}} T B Z_{\mathrm{R}}$ & $3.9 \mathrm{~d}$ & $2.3 \mathrm{~d}$ & $\mathrm{FLU}_{\mathrm{R}} \mathrm{PYR}_{\mathrm{R}} \mathrm{TBZ} \mathrm{R}_{\mathrm{R}}$ \\
\hline
\end{tabular}

${ }^{v}$ Mycelial growth on potato dextrose agar (PDA) at $25^{\circ} \mathrm{C}$ expressed in millimeters per day. Numbers within the same column followed by different letters are statistically significant according to the Waller-Duncan $K$-ratio $t$ test, where $K=100(P=0.05)$.

${ }^{\mathrm{w}} \mathrm{P}=$ parental isolate sensitive to fludioxonil and resistant to pyrimethanil and thiabendazole, and $\mathrm{C}=$ conditioned multiresistant isolate capable of growing with fludioxonil at $0.5 \mu \mathrm{g} / \mathrm{ml}$.

${ }^{x}$ Mean values for effective concentrations for inhibiting $50 \%$ of mycelial growth $\left(\mathrm{EC}_{50}\right)$ for Botrytis cinerea isolates was determined using PDA amended with technical-grade fludioxonil and calculated using linear regression models in SAS.

${ }^{y}$ B. cinerea isolates were considered resistant $(\mathrm{R})$ if they grew or sensitive (S) if they did not grow on discriminatory doses of PDA amended with technical-grade fludioxonil (FLU) at $0.5 \mu \mathrm{g} / \mathrm{ml}$, Richard's defined medium amended with pyrimethanil (PYR) at $1 \mu \mathrm{g} / \mathrm{ml}$, or PDA with thiabendazole (TBZ) at $10 \mu \mathrm{g} / \mathrm{ml}$.

${ }^{\mathrm{z}}$ Phenotype after 10 generations without selection; nd = not determined. 
2014; Staats et al. 2005). MegaBLAST analysis confirms our morphological identification at the species level and rules out the possibility of a different Botrytis spp. that could have represented an emerging apple pathogen. It is conceivable that a new species may be found causing postharvest decay of apple in the future, similar to recent findings for strawberry (B. caroliniana), daylily (B. deweyae), blueberry (B. californica), and table grape (B. sinoviticola) (GrantDownton et al. 2014; Li et al. 2012; Saito et al. 2016; Zhou et al. 2014). Our original hypothesis was that the $B$. cinerea isolates from Pennsylvania would be genetically similar to those from South Carolina, based on geographic proximity. However, analysis using the GAPDH locus revealed otherwise, because isolates from Pennsylvania composed a distinct clade from $B$. cinerea isolates from South Carolina, China, and The Netherlands.

This is the first investigation to demonstrate that $B$. cinerea can rapidly develop resistance to FLU in isolates that are dual resistant to postharvest fungicides following exposure to the active ingredient in Scholar. Most of the investigations concerning fungicide-resistant gray mold have been focused on naturally occurring B. cinerea isolates from apple, blackberry, and strawberry in the United States (Fernández-Ortuño et al. 2015; Li et al. 2014; Zhao et al. 2010). In our study, seven of the eight isolates grew on a discriminatory dose of FLU after conditioning and had $\mathrm{EC}_{50}$ values greater $(>50 \mu \mathrm{g} / \mathrm{ml})$ than what has been reported in the literature for a naturally occurring FLU-reduced-sensitive $B$. cinerea isolate from apple (Zhao et al. 2010). Furthermore, analysis of $B$. cinerea isolates with conditioned resistance to FLU showed that they were osmosensitive and that resistance was stable in the absence of selection pressure, which is consistent with reports concerning FLU resistance in B. cinerea ( $\mathrm{Li}$ et al. 2014; Zhao et al. 2010). The $B$. cinerea isolates with conditioned resistance to FLU also had reduced fitness because their growth rates were approximately $50 \%$ less on PDA compared with growth of their parental strains on the same medium. However, they still caused decay on apple fruit treated with Scholar, Penbotec, and Mertect. Despite their reduction in growth and aggressiveness, these multiresistant isolates have the potential to cause decay in the packinghouse because the currently labeled materials (with the possible exception of Academy) would be ineffective.

In $B$. cinerea, one of the genes responsible for the extracellular transport of fungicides is a homolog of the $\operatorname{atr} B$ gene from Aspergillus nidulans (Vermeulen et al. 2001). Resistance to FLU has been associated with a mutation in the Mrrl transcription factor and is designated multidrug resistance 1 (MDR1) for $B$. cinerea from grape, blackberry, and strawberry (Kretschmer et al. 2009; $\mathrm{Li}$ et al. 2014). Analysis of the C-terminal portion of $M r r l$ from the parental $B$. cinerea isolates investigated in this study contained the expected arginine residue at position 632, which coincided with susceptibility to FLU. However, analysis of three multiresistant B. cinerea isolates growing on FLU at 0.5 , 1.0 , and $10 \mu \mathrm{g} / \mathrm{ml}$ lacked the expected isoleucine residue at position 632 and, instead, showed arginine. These results indicate that the mechanisms of resistance that occur during conditioning in the laboratory may be different from what is naturally occurring in isolates from the field (Kretschmer et al. 2009; Li et al. 2014). Other common mechanisms, including sequestration, detoxification, or metabolism of FLU, may be acting in isolation or in combination to confer conditioned resistance in these isolates and is the subject of future investigations in our laboratory using omics-based approaches.

In conclusion, $B$. cinerea isolates with dual resistance to TBZ and PYR have been detected and characterized for the first time from isolates originating from a commercial packing and storage facility in the Mid-Atlantic region. Results from this study have demonstrated that isolates with dual resistance to TBZ and PYR have the potential to rapidly develop resistance to FLU, which can cause decay on postharvest fungicide-treated fruit. Our findings demonstrated that the development of multiple resistance to postharvest fungicides in $B$. cinerea isolates is a potential threat to control of apple gray mold because such strains may be able to persist in the packinghouse in the absence of the fungicide selection pressure. As with any decay control program, integration of cultural and chemical practices is essential for optimal control and to preserve the longevity and efficacy of these chemicals. Therefore, it is sensible to rotate the use of postharvest fungicides with different active ingredients frequently, according to the Fungicide Resistance Action Committee code, based on fungicide use histories not only in the postharvest handling and storage facility but also in the field.

\section{ACKNOWLEDGMENTS}

Use of a company or product name by the U.S. Department of Agriculture does not imply approval or recommendation of the product to the exclusion of others that may also be suitable. This research was funded by USDAARS project number 8042-42430-014-00D via National Program 303-Plant Diseases and by competitive grant funds awarded to W. M. Jurick II by stakeholders at the State Horticulture Association of Pennsylvania. We thank K. Gu for initial work conducting the in vitro fungicide assays to phenotype the $B$. cinerea isolates.

\section{LITERATURE CITED}

Fernández-Ortuño, D., Grabke, A., Li, X., and Schnable, G. 2015. Independent emergence of resistance to seven chemical classes of fungicides in Botrytis cinerea. Phytopathology 105:424-432.

Fillinger, S., Ajouz, S., Nicot, P. C., Leroux, P., and Bardin, M. 2012. Functional and structural comparison of pyrrolnitrin- and iprodione modifications in the class III histidine-kinase Bos 1 of Botrytis cinerea. PLoS One 7: e42520.

Grant-Downton, R. T., Terhem, R. B., Kapralov, M. V., Mehdi, S., Rodriguez-Enriquez, M. J., Gurr, S. J., van Kan, J. A. L., and Dewey, F. M. 2014. A novel Botrytis species is associated with a newly emergent foliar disease in cultivated Hemerocallis. PLoS One 9:e89272.

Hilber, U. W., Schwinn, F. J., and Schuepp, H. 1995. Comparative resistance patterns of fludioxonil and vinvlozolin in Botryotinia fuckeliana. J. Phytopathol. 143:423-428.

Jarvis, R. W. 1977. Botryotinia and Botrytis Species: Taxonomy, Physiology, and Pathogenicity. A Guide to the Literature. Canada Department of Agriculture, Ottawa, ON Canada.

Kanetis, L., Förster, H., Jones, C. A., Borkovich, K. A., and Adaskaveg, J. E. 2008. Characterization of genetic and biochemical mechanisms of fludioxonil and pyrimethanil resistance in field isolates of Penicillium digitatum. Phytopathology 98:205-214.

Kim, Y. K., and Xiao, C. L. 2008. Distribution and incidence of Sphaeropsis rot in apple in Washington State. Plant Dis. 92:940-946.

Kretschmer, M., Leroch, M., Mosback, A., Walker, S., Fillinger, S., Mernke, D., Schoonbeek, H., Pradier, J., Leroux, P., De Waard, M., and Hahn, M. 2009. Fungicide-driven evolution and molecular basis of multidrug resistance in field populations of the gray mould fungus Botrytis cinerea. PLoS Pathog. 5:e1000696.

Li, A., Fernández-Ortuño, D., Grabke, A., and Schnable, G. 2014. Resistance to fludioxonil in Botrytis cinerea isolates from blackberry and strawberry. Phytopathology 104:724-732.

Li, H. X., and Xiao, C. L. 2008. Characterization of fludioxonil-resistant and pyrimethanil-resistant phenotypes of Penicillium expansum from apple. Phytopathology 98:427-435.

Li, X., Fernández-Ortuño, D., Chai, W., Wang, F., and Schnable, G. 2012. Identification and prevalence of Botrytis spp. from blackberry and strawberry fields of the Carolinas. Plant Dis. 96:1634-1637.

Robinson, T. L., Brown, S. K., Fazio, G., and Aldwinkle, H. S. 2014. Harvest and handling. Pages 6-7 in: Compendium of Apple and Pear Diseases and Pests, second ed. T. B. Sutton, H. S. Aldwinckle, A. M. Agnello, and J. F. Walgenbach, eds. American Phytopathological Society Press, St. Paul, MN.

Saito, S., Margosan, D., Michailides, T. J., and Xiao, X. L. 2016. Botrytis californica, a new cryptic species in the $B$. cinerea species complex causing gray mold in blueberries and table grapes. Mycologia 108: 330-343.

Staats, M., van Baarlen, P., and van Kan, J. A. L. 2005. Molecular phylogeny of the plant pathogenic genus Botrytis and the evolution of host specificity. Mol. Biol. Evol. 22:333-346. 
Vermeulen, T. Schoonbeek, H., and De Waard, M. A. 2001. The ABC transporter BcatrB from Botrytis cinerea is a determinant of the activity of the phenylpyrrole fungicide fludioxonil. Pest Manage. Sci. 57: 393-402.

Xiao, C. L. 2014. Gray mold. Pages 77-78 in: Compendium of Apple and Pear Diseases and Pests. T. B. Sutton, H. S. Aldwinkle, A. M. Agnello, and J. F. Walgenbach, eds. American Phytopathological Society Press, St. Paul, MN.

Xiao, C. L., and Boal, R. J. 2009. Residual activity of fludioxonil and pyrimethanil against Penicillium expansum on apple fruit. Plant Dis. 93:1003-1008.
Zhao, H., Kim, Y. K., Huang, L., and Xiao, C. L. 2010. Resistance to thiabendazole and baseline sensitivity to fludioxonil and pyrimethanil in Botrytis cinerea populations from apple and pear in Washington State. Postharvest Biol. Technol. 56:12-18.

Zhou, Y. J., Zhang, J., Wang, X. D., Yang, L., Jiang, D. H., Li, G. Q., Hsiang, T., and Zhuang, W. Y. 2014. Morphological and phylogenetic identification of Botrytis sinoviticola, a novel cryptic species causing gray mold disease of table grapes (Vitis vinifera) in China. Mycologia 106:43-56. 